\title{
DIKOTOMI IMAM-AWAM SEBAGAI TANTANGAN \\ DALAM MEMBANGUN TATA DUNIA: \\ SEBUAH PEMBELAJARAN DARI KEUSKUPAN SIBOLGA
}

Oleh: Elisabet Subiati

\begin{abstract}
Abstrak:
Artikel ini bertujuan mengangkat sebuah issu tentang sebab-sebab terjadinya dikotomi imamawam dalam kehidupan menggereja yang nyata dalam praktek pastor sentris. Adapun bentuk praktek pastor sentris yang dimaksudkan dalam tulisan ini yakni Gereja Kultis/ ritual, di mana upacara-upacara peribadatan menjadi orientasi utama dalam kehidupan menggereja. Gereja Kultis/ ritual memberikan posisi sentral kepada spesialis kultis, yakni para imam (pastor). Dalam kaitan dengan Gereja Kultis/ ritual ini imam (pastor) dilihat sebagai tokoh yang paling menguasai seluk beluk ibadat dalam agama Katolik, dan sebagai pemimpin utama dalam urusan penyucian. Adapun yang menjadi tekanan utama dalam Gereja Kultis/ ritual adalah pada peranan imam yang menguduskan. Praktek pastor sentris tidak sesuai dengan gambaran hidup menggereja menurut Konsili Vatikan II. Karena praktek pastor sentris "mematikan" peranan anggota-anggota Gereja, khususnya kaum awam. Padahal sebagai anggota-anggota umat Allah, kaum awam memiliki martabat yang sama dengan para diakon, imam dan uskup. Penulis mengangkat tema ini dengan memperlihatkan konteks kehidupan Gereja di Keuskupan Sibolga. Di Keuskupan Sibolga pemberdayaan petugas pastoral merupakan salah satu langkah strategis dalam perwujudan kerja-sama imam dan awam. Kehidupan menggereja di keuskupan Sibolga untuk beberapa tahun pernah mengalami dikotomi imam-awam sebagai akibat praktek pastor sentris.
\end{abstract}

Kata-kata kunci: Dikotomi imam-awam, Pastor sentris, Pemberdayaan petugas pastoral

\section{Pengantar}

I

stilah dikotomi imam-awam dirasakan oleh penulis negatif, apalagi jika memahami arti dikotomi yang terdapat dalam Kamus Besar Bahasa Indonesia. Menurut Kamus Besar Bahasa Indonesia (KBBI) istilah dikotomi/di.ko.to.mi/ diartikan sebagai pembagian atas dua kelompok yang saling bertentangan. Selanjutnya untuk menjelasakan pengertian dikotomi, KBBI memberikan contoh penggunaan kata dikotomi di bidang politik, adalah pembagian dua kelompok yang saling bertentangan, yang sulit diintegrasikan. Di bidang politik istilah dikotomi sering dikaitkan dengan agama dan ilmu pengetahuan, dan keduanya jelas berbeda (bdk. KBBI versi online).

Istilah dikotomi imam-awam, juga akan menjadi tidak sesuai jika dimaksudkan untuk melihat perbedaan imam-awam, apalagi dari sudut pandang Konsili Vatikan II. Sementara pandangan-pandangan dari Konsili Vatikan II dan juga seruan-seruan Apostolik dari Paus serta 
hasil sinode dari para Uskup pasca Konsili Vatikan II menyatakan dengan jelas bahwa perbedaan antara imam dan awam merupakan perbedaan yang sangat mungkin untuk diintegarasikan. Namun tidak dapat disangkal bahwa dalam hidup menggereja, dikotomi imam-awam pernah ada, misalnya yang terjadi di Keuskupan Sibolga (Lih. bahan bacaan dasar untuk persiapan sinode pertama keuskupan Sibolga:"Gereja Kultis/ ritual dengan pastor sebagai pusat”). Bagaimana bentuk dikotomi imam-awam yang pernah ada dikeuskupan Sibolga akan dilihat lebih lanjut lagi. Jika dikotomi imam-awam ada, apakah hal tersebut sesuatu yang baik dan sejalan dengan pandangan Gereja? Dan selain itu, apakah jika dikotomi imam-awam ada, akankah ditemukan “tantangan positif" untuk membangun tata dunia?

Sehubungan dengan pertanyaan-pertanyaan tersebut maka tulisan ini akan menyajikan halhal berikut ini:

1) Pandangan Konsili Vatikan II tentang peranan imam dan awam dalam membangun tata dunia

2) Pengalaman hidup mengereja di keuskupan Sibolga dari Gereja Kultis/ ritual dengan pastor sebagai pusat, menjadi Gereja yang berjuang, membebaskan dan lebih tanggap terhadap situasi masyarakat.

\section{Pandangan Konsili Vatikan II tentang peranan imam dan awam}

\section{Menyimak sejauh mana "perbedaan" Imam-Awam dalam dokumen Gereja}

Pandangan-pandangan Konsili Vatikan II yang menunjukkan perbedaan antara imam dan awam berkaitan dengan bagaimana mereka menjalankan fungsi dalam mengemban imamat Yesus Kristus dan corak hidup yang dijalankan (LG.10; KWI, 1996: 362). Supaya kita dapat mengerti bahwa perbedaan antara imam dan awam bukanlah perbedaan yang tidak dapat diintegrasikan, baiklah kita melihat beberapa hal berikut ini:

\section{a) Umat Allah}

Lumen Gentium Konstitusi Dogmatis tentang Gereja, yang merupakan salah satu hasil Konsili Vatikan II, nomor 9 menyebut bahwa Umat Allah adalah segala kaum, yang diselamatkan oleh Allah sendiri, yang dibentuk oleh Allah sendiri, yang disebut sebagai Gereja dan Yesus Kristuslah sebagai kepala. Sementara itu Roh Allah hidup di dalam hati umat yang dibentuknya tersebut. Cinta Kasih menjadi hukum Umat Allah tersebut. Dan bagi Umat Allah yang menjadi tujuan adalah Kerajaan Allah. Umat yang telah dibentuk oleh Allah ini menerima perutusan untuk mewartakan dan mewujudkan kerajaan Allah di tengah semua bangsa (LG. 5).

Umat Allah mengambil bagian dalam tugas imamat Kristus. Imamat umum kaum beriman dan imamat hierarkis saling terarahkan, meskipun berbeda hakikat dan tingkatnya, sebab keduanya mengambil bagian di dalam satu imamat Kristus (LG 10). Imamat umum itu 
diwujudkan dengan menerima sakramen-sakramen maupun dengan mengamalkan keutamaankeutamaan (LG.11). Umat Allah itu juga mengambil bagian dalam tugas kenabian Kristus, yakni dengan memberikan kesaksian hidup kristiani, yang diwarnai oleh iman dan kasih (LG. 12).

\section{b) Susunan Hierarkis Gereja}

Untuk menggembalakan dan mengembangkan umat Allah, Tuhan Yesus mengadakan dalam Gereja aneka pelayanan. Ia telah mengutus para rasul seperti Ia sendiri diutus oleh Bapa. Kemudian, penganti-penganti para rasul, yakni para uskup, dikehendaki-Nya menjadi gembalagembala bagi umat-Nya hingga akhir zaman (LG. 18). Para Rasul itu dibentuk-Nya menjadi semacam dewan atau badan yang tetap. Sebagai ketua dewan itu, diangkat-Nya Petrus, yang dipilih dari antara mereka. Ia mengutus mereka pertama-tama kepada umat Israel, lalu kepada semua bangsa Israel (LG. 19).

Supaya perutusan yang dipercayakan kepada para rasul itu dapat berlanjut setelah mereka meninggal, mereka menyerahkan tugas itu kepada orang-orang terdekat. Menurut tradisi, yang mendapat tempat utama ialah uskup (Gitowiratmo, 2003:53). Demikianlah, menurut kesaksian Santo Ireneus, melalui mereka yang oleh para rasul diangkat menjadi uskup serta para pengganti mereka sampai zaman kita, tradisi rasuli dinyatakan dan dipelihara di seluruh dunia. Dalam melayani jemaat, para uskup itu kemudian dibantu oleh para imam dan para daikon (LG. 20). Melalui dan setelah penahbisan, uskup diberi tugas mengajar, menyucikan, dan menggembalakan jemaat (LG. 21). Paus sebagai penganti Petrus, bersama-sama semua uskup, membentuk sebuah dewan. Dewan para uskup itu hanya memiliki wibawa bila dan selama bersama dengan paus, sebagai pengganti Petrus (LG. 22).

Setiap uskup mengetuai gereja partikular, tetapi sebagai anggota Dewan Para Uskup ia wajib menaruh perhatian terhadap seluruh Gereja (LG. 23). Tugas yang dipercayakan kepada para gembala itu merupakan pengabdian (LG. 24). Diantara tugas-tugas utama para uskup, yang terpenting adalah pewartaan Injil. Dalam hal itu, Paus memiliki ciri "tidak dapat sesat" saat menyampaikan ajaran iman pada tingkat dogma. Tetapi Paus tidak memiliki hak memberikan wahyu umum baru (LG. 25). Para uskup wajib membantu umat dengan teladan hidup mereka, dengan mengendalikan perilaku mereka dan menjauhkan umat dari segala cela (LG. 26). Para uskup membimbing gereja-gereja partikular dengan kekuasaan sendiri. Mereka bukanlah wakil Paus, uskup Roma (LG. 27).

Para imam, sebagai para pembantu uskup, tidak menerima kepenuhan imamat. Dalam melaksanakan wewenang dan tugas, mereka tergantung pada uskup mereka (LG. 27). Para diakon ditahbiskan untuk pelayanan imamat. Mereka melayani umat dengan pelayanan liturgi, pelayanan Sabda, dan amal kasih. Dengan izin Paus tahbisan diakon dapat diterimakan juga kepada pria yang sudah berkeluarga (LG. 29).

\section{c) Imamat dalam Gereja}


Presbyterorum Ordinis -salah satu Dokumen Konsili Vatikan II- yang berbicara tentang kehidupan dan pelayanan para imam menyatakan bahwa "dia yang menerima kuasa tahbisan suci adalah pelayan yang diangkat sendiri oleh Allah, yang berasal dari anggota umat juga, yang tujuannya supaya memadukan umat menjadi satu tubuh. Kuasa tahbisan suci tersebut untuk mempersembahkan Ekaristi, dan mengampuni dosa-dosa dan demi Kristus secara resmi menunaikan tugas imamat"(PO.2). Pelayanan tersebut menuntut bahwa mereka tidak menyesuaikan diri dengan dunia, namun sekaligus juga menuntut bahwa mereka hidup di tengah masyarakat. Untuk dapat mencapai tujuan itu, pentinglah peranan keutamaan-keutamaan, misalnya kebaikan hati, kejujuran, keteguhan dan ketabahan, adil dan sopan (PO. 3)

\section{d) Pelayanan para Imam}

Sebagai rekan-rekan kerja para uskup, para imam pertama-tama wajib mewartaka Injil kepada semua orang pewartaan sabda itu dilaksanakan dengan aneka cara, menanggapi pelbagai kebutuhan para pendengarnya dan menurut karisma para pewarta (PO. 4). Bersama para uskup, para imam juga wajib melayani karya pengudusan. Hal itu terutama mereka lakukan dengan melayani sakramen-sakramen, terutama sakramen Ekaristi (PO. 5). Bersama para uskup, para imam juga menunaikan tugas Kristus sebagai kepala dan gembala, dengan menghimpunkan keluarga Allah sebagai rukun persaudaraan yang sehati sejiwa. Tugas penggembalaan itu tidak terbatas pada reksa pastoral terhadap anggota umat secara perorangan melainkan menggembalakan seluruh jemaat agar menjadi umat Allah yang sejati (PO. 6).

Semua imam bersama para uskup menghayati satu imamat. Hal itu menuntut adanya persekutuan hirarkis antara para imam dan dewan para uskup. Karena itu hendaklah para uskup memandang para imam sebagai saudara dan sahabat mereka serta memperhatikan kesejahteraan rohani dan jasmani mereka. Sementara itu hendaklah para imam berpaut pada uskup mereka dengan kasih yang tulus dan sikap patuh (PO. 7). Berkat tahbisan semua imam bersatu dalam persaudaraan sakramental. Khususnya dalam satu keuskupan mereka merupakan satu presbyterium, sebab meskipun mereka menjalankan bermacam-macam tugas, mereka hanya mengemban satu imamat. Karena itu pentinglah bahwa semua imam, baik diosesan maupun religious saling membantu supaya mereka selalu mengerjakan karya bersama demi kebenaran (PO. 8). Hendaknya para imam mengakui dan mendukung martabat kaum awam dan perutusan Gereja yang dipercayakan kepada mereka. Sambil menguji roh-roh apakah memang berasal dari Allah, hendaknya awam, mengakuinya dengan gembira dan mendukung perkembangann ya (PO. 9).

\section{e) Imamat Jabatan}

Paus Yohanes Paulus II dalam Anjuran Apostolis Pastores Dabo Vobis, tahun1992, mengatakan bahwa hakikat dan perutusan yang terkait dengan imamat jabatan, perlu dipahami dalam kaitan dengan jati diri Gereja sebagai misteri, persekutuan, dan perutusan ( PDV. 12)

Kristus adalah imam yang kekal (PDV. 13). Selanjutnya Yesus mempercayakan kepada para rasul-Nya tugas meneruskan misi-Nya untuk menyelamatkan manusia, sambil tetap bersatu 
dengan-Nya (PDV. 14). Pada gilirannya para rasul kemudian memanggil orang-orang lain untuk menjadi uskup, imam, dan daikon, lalu mengutus mereka kepada semua orang di segala zaman(PDV. 15).

Para bapa sinode yang lalu menekankan bahwa para imam itu menempati tempat bukan hanya di dalam Gereja, melainkan juga di garis depan Gereja, sebab imamat merupakan salah satu dari unsur-unsur hakiki Gereja; meskipun demikian, imam juga harus menjadi hamba Gereja (PDV. 16).

Pelayanan para imam merupakan karya kolektif; setiap imam harus berkarya dalam kesatuan dengan uskup dan imam-imam yang lain; bahkan imam juga harus membangun relasi yang positif dengan kaum awam(PDV. 17). Saat ini dalam kaitan dengan urgensi pelaksanaan evangelisasi baru para imam harus ikut serta menunaikan misi untuk mewartakan kabar baik, demi nama dan pribadi Kristus (PDV. 18).

\section{f) Kaum Awam}

Menurut Lumen Gentium nomor 31, kaum Awam adalah semua orang beriman kristiani kecuali mereka yang termasuk golongan imam atau golongan religious (misalnya biarawan dan biarawati). Ciri khas mereka adalah keduniaannya. Berdasarkan panggilan mereka yang khas, kaum awam wajib mencari Kerajaan Allah dengan mengurusi hal-hal yang fana dan mengaturnya sesuai dengan kehendak Allah (LG. 31; Prasetya, 2003:23).

Sebagai anggota-anggota umat Allah, kaum awam memiliki martabat yang sama dengan para diakon, imam dan uskup. Dengan rumusan lain sebagai umat Allah kaum awam itu bersaudara dengan para imam dan uskup (LG. 32). Segenap kaum awam dipanggil untuk ikut mengambil bagian dalam perkembangan Gereja, antara lain juga dapat dipanggil untuk bekerja sama langsung dengan hierarki (LG. 33). Kaum awam dipanggil untuk mengambil bagian dalam imamat Kristus, untuk melaksanakan ibadat rohani, agar Allah dimuliaan dan umat manusia diselamatkan. Demikianlah kaum awam pun adalah para penyembah Allah yang di mana-mana hidup dengan suci, membaktikan dunia kepada Allah (LG. 34). Kaum awam juga dipanggil untuk mengambil bagian dalam tugas kenabiaan Kristus. Karena itu, juga kalau mereka sibuk dengan urusan keduniaan, kaum awam dapat dan harus menjalankan kegiatan yang berharga untuk mewartakan injil kepada dunia. Oleh karena itu, hendaklah kaum awam dengan tekun berusaha mendalami kebenaran yang diwahyukan (LG. 35).

Kaum awam juga dipanggil untuk mengambil bagian dalam tugas rajawi Kristus antara lain dengan menyehatkan lembaga-lembaga dan kondisi-kondisi masyarakat. Demi terlaksannya tata keselamatan hendaklah kaum awam membuat pembedaan dengan cermat antara hak-hak dan kewajiban-kewajiban mereka sebagai anggota masyarakat. Hendaklah mereka juga berusaha memadukan keduannya, dengan mengingat bahwa dalam perkara duniawi mana pun mereka juga wajib menganut suara hati kristiani (LG. 36). 
Kaum awam berhak menerima harta-rohani Gereja melalui pelayan para gembala. Maka hendaklah kaum awam mengemukakan kebutuhan-kebutuhan mereka kepada para imam dengan kebebasan dan kepercayaan. Sebaliknya hendaklah para gembala hierarkis mengakui dan memajukan martabat serta tangung jawab kaum awam dalam Gereja. Dari persaudaraan antara kaum awam dan para gembala itu dapat diharapkan banyak manfaat bagi Gereja (LG. 37). Semua orang beriman wajib memperkaya dunia dengan buah-buah rohani (LG. 38). Setiap orang awam wajib menjadi saksi kebangkitan dan kehidupan serta menjadi tanda Allah yang hidup di hadapan dunia. Semuanya wajib memperkaya dunia dengan buah-buah rohani dan menyebarkan semangat yang menjiwai mereka yang miskin, lemah lembut dan cinta damai (LG. 38).

Salah satu dokumen Konsili Vatikan II yaitu Apostolicam Actuositatem yang berbicara tentang Kerasulan Awam dalam artikel 2 menyatakan bahwa "panggilan kaum awam sama dengan para imam mengemban tri tugas Kristus (sebagai imam, nabi dan raja). Ciri khas kaum awam, berbeda dari para imam, adalah bahwa kaum awam hidup di tengah-tengah masyarakat dan mengurus perkara-perkara duniawi. Kerasulan awam seperti kerasulan para imam, dijalankan dalam iman, harapan, dan kasih kepada Allah. Selain itu kerasulan tersebut juga dijalankan dengan memanfaatkan karisma-karisma yang dianugerahkan oleh Roh kudus, kepada masing-masing, demi kepentingan seluruh umat" (AA. 3). Kesuburan kerasulan awam tergantung pada perstuan para rasul awam itu dengan Kristus. Mereka diharapkan selalu berusaha berbuat baik kepada semua orang. Mereka melaksnakan kerasulan sesuai dengan status hidup mereka (menikah atau tidak, profersional atau sosial) dan kelompok yang mereka ikuti yang memiliki spiritualitas khas (AA. 4).

Adapun tujuan kerasulan awam yaitu untuk merasuki dan menyempurnakan tata dunia dengan semangat Injili (AA. 5). Kerasulan awam dijalankan baik melalui kesaksian hidup yang berciri kristiani maupun melalui pewartaan Injil (AA. 6). Kaum awam wajib menerima hal berikut sebagai tugasnya yang khas: pembaharuan tata dunia dalam semangat Injili (AA. 7). Semua kerasulan itu harus bersumber pada cinta kasih dan menimba kekuatan darinya ( AA. 8).

\section{g) Martabat Awam}

Hasil Sinode para Uskup sedunia pada tahun 1987, yang termuat dalam Christi Fideles Laici, nomor 8 menyatakan bahwa martabat kaum awam dalam Gereja hanya dapat dipahami dengan tepat bila Gereja dimengerti sebgai sebuah persekutuan. Seperti para imam dan rohaniwan/ rohaniwati, seorang awam digabungkan dengan Gereja karena baptisan; tetapi berbeda dari para imam dan rohaniwan/ rohaniwati, seorang awam menjalani hidupnya seharihari di tengah-tengah masyarakat dan mengurus hal-hal "duniawi". Dengan baptisan seorang memperoleh martabat; ia disatukan dengan Kristus, Gereja, dan Allah sendiri. Dengan baptisan seorang dijadikan anak Allah karena ia disatukan dengan Kristus, Putra Allah.

Dengan baptisan, seorang juga disatukan dengan Gereja menjadi anggota Gereja, tubuh Kristus sendiri. Dengan baptisan seseorang diurapi oleh Roh Kudus, dijadikan kenisah rohani (artinya, Allah hadir secara rohani di dalam dirinya). Dengan baptisan seseorang juga mendapat 
tugas dan wewenang baru, yakni untuk mengambil bagian dalam karya Kristus sebagai imam, nabi dan raja. Ia menjalankan tugasnya sebagai imam dengan mempersembahkan seluruh hidupnya kepada Allah, dengan menghayati seluruh hidupnya itu di dalam Roh. Ia menjalankan hidupnya sebagai nabi dengan menerima injil bagi dirinya dan mewartakannya kepada orangorang lain. Ia menjalankan tugasnya sebagai raja dengan mengalahkan kerajaan setan dan ikut menegakkan Kerajaan Allah (CFL. 9-14).

Kekhasan kaum awam ialah bahwa mereka hidup di dunia, hidup di tengah keluarga dan masyarakat; dengan demikian dunia menjadi tempat dan sarana bagi mereka dalam menjalani tugas sebagai imam, nabi dan raja. Seperti para imam dan para rohaniwan/ rohaniwati, kaum awam juga dipanggil menuju kekudusan dengan mengikuti dan meneladan Tuhan Yesus terutama dengan mempraktekkan kasih yang sempurna untuk mencapai kekudusan itu, kaum awam harus memandang kehidupan sehari-hari mereka di tengah masyarakat sebagai peluang untuk menyatukan diri mereka dengan Allah, dengan mengasihi Allah dan sesama (CFL. 15-17).

\section{h) Partisipasi kaum Awam}

Berdasarkan pada sakramen Baptis dan Sakramen Penguatan yang telah diterima, sesuai dengan peraturan Gereja, sejauh diperlukan, beberapa orang awam dapat diberi tugas tertentu dalam struktur pastoral Gereja, yang pada dasarnya merupakan tugas paraa anggota hierarki (CFL. 22-23).

Selain mencurahkan karunia hierarkis kepada para pejabat Gereja, Roh Kudus mencurahkan karunia-karunia karismatis kepada banyak anggota jemaat beriman. Karismakarisma itu dianugerahkan dalam berbagai rupa, namun demi satu tujuan utama, yakni pembangunan jemaat. Oaring yang menerima karisma haruslah bersyukur dan sekaligus bersikap rendah hati. Ia harus menghormati hak pimpinan Gereja untuk menilai autentisitas karisma yang diterimanya. Kaum awam berpartisipasi di dalam hidup Gereja bukan hanya dengan memanfaatkan karisma-karisma yang mereka terima, melainkan juga dengan banyak cara lain, yakni dengan keterlibatannya di dalam Gereja, baik yang universal maupun yang particular (CFL 24-25). Partisipasi kaum awam di paroki berada dalam persatuan erat dengan imam-imam mereka. Di paroki kaum awam dapat membangkitkan kembali semangat missioner terhadap kaum tak beriman maupun terhadap sesama kaum beriman yang imannya sudah lesu atau hampir mati (CFL 26-27).

\section{Pengalaman hidup mengereja di keuskupan Sibolga dari Gereja Kultis/ ritual dengan pastor sebagai pusat, menjadi Gereja yang berjuang, membebaskan dan lebih tanggap terhadap situasi masyarakat.}

\section{Dikotomi Imam-Awam}


Jika membaca dan memahami apa yang dituliskan dalam dokumen-dokumen Gereja, kita bisa menyimpulkan bahwa antara imam dan awam sebetulnya tidaklah bertentangan. Mereka tidaklah saling bersaing di dalam Gereja, sebaliknya ada saling ketergantungan satu dengan yang lain (Prasetya, 2007: 21), maka sebetulnya secara alami akan terjadi suatu kerja sama yang saling melengkapi. Pertanyaannya adalah: "situasi ideal yang dicita-citakan seperti ini apakah sudah terjadi di Keuskupan Sibolga?" Untuk menjawab hal tersebut, ada baiknya jika kita mereflesikan kembali situasi atau kenyataan yang pernah terjadi di Keuskupan Sibolga.

\section{Gereja Kultis/ ritual Dengan Pastor Sebagai Pusat}

Dalam proses sinode Keuskupan Sibolga selama 1 tahun, telah diadakan banyak kegiatan, antara lain Ansos di kelompok-kelompok dan penelitian. Laporan dari kegiatan-kegiatan ini memberikan salah satu gambaran Gereja yang menonjol di Keuskupan ini, yakni Gereja kultis dengan pastor sebagai pusatnya (bdk. Keuskupan Sibolga, 2010).

Dengan isitilah Gereja kultis atau Gereja ritual dimaksudkan bahwa orientasi utama dari Gereja adalah ibadah. Aspek-aspek yang lain dalam kehidupan menggereja kurang mendapat perhatian. Kalau pun itu diperhatikan, tidak dianggap sebagai bagian integral dalam kehidupan menggereja.

Diagram berikut ini coba menggambarkan model Gereja seperti ini.

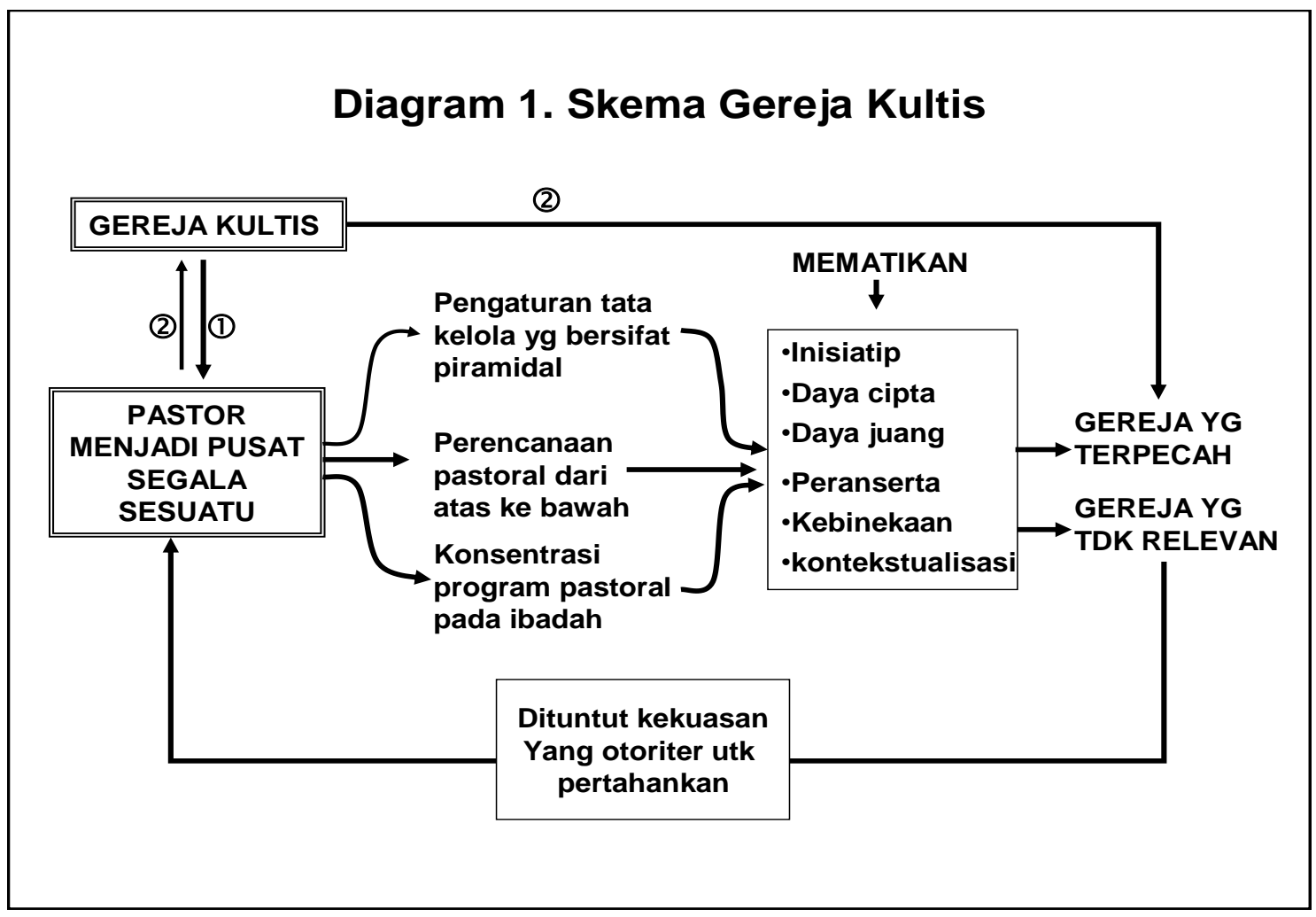


Gereja kultis memberikan posisi sentral kepada spesialis kultis, yakni para imam (pastor). Imam di sini terutama dilihat sebagai orang yang paling menguasai seluk beluk ibadah dalam agama Katolik dan sebagai pemimpin utama dalam urusan penyucian. Tekanan utama di sini pada peranan imam yang menguduskan. Karena itu, seorang imam dituntut untuk menjadi pribadi yang saleh, pribadi yang dibedakan dari umat kebanyakan, dipisahkan dari yang lain. Bercampur baur dengan umat kebanyakan dianggap mengurangkan daya sakti dari seorang imam/pastor. Hanya dengan jalan hidup yang keras, saleh, terpisah dari umat, seorang imam mampu menghadirkan daya magis, baik untuk memberikan berkah maupun mendatangkan kehancuran (berkat \& kutuk).

\section{Akibat-akibat buruk praktek Gereja Kultis/ ritus}

Konsentrasi kekuasaan pada diri spesialis kultis yang dianggap memiliki daya magis mengakibatkan:

1. Pengaturan organisasi gereja bersifat piramidal,

2. Perencanaan pastoral, kalau ada, bersifat "dari atas ke bawah,"

3. Konsentrasi program pastoral pada ibadah dan hal-hal yang terkait dengan ibadah.

Dalam waktu yang relatif lama, model Gereja seperti ini mematikan:

1. Insiatip dari umat

2. Kreatifitas anggota Gereja, khususnya kaum awam

3. Daya juang dari anggota,

4. Peran serta umat,

5. Kebinekaan/kejamakan dalam program pastoral yang bersumber dari upaya

6. Kontekstualisasi dalam reksa pastoral. Gereja seperti ini membuat umat tergantung pada pastor, tidak memberdayakan.

Gereja seperti ini memisahkan ibadah dari perjuangan kemasyarakatan karena dibuat pembedaan yang tegas antara apa yang dianggap suci/ sakral dan apa yang dianggap duniawi/ profan. Ibadah tidak memberikan inspirasi/ilham untuk perjuangan kemasyarakatan, tidak menjadi pegangan nilai dan pedoman dalam perjuangan di bidang ekonomi, politik dan dalam relasi sosial. Kekristenan juga tidak mampu untuk secara kritis berdialog dengan budaya setempat. Sebaliknya perjuangan kemasyarakatan tidak menjadi inspirasi dalam perayaan kultis. Gereja seperti ini adalah Gereja yang terpecah.

Ibadah yang terpisah dari perjuangan hidup dan tidak memberikan inspirasi untuk umat berjuang dalam dunia ekonomi dan politik, mengembangkan relasi yang baik antar sesama dan 
memurnikan budaya setempat menyebabkan Gereja tidak relevan untuk kebanyakan umat. Karena itu ikatan dengan Gereja menjadi sangat longgar, hanya dipakai sekedar sebagai penanda identitas dalam negara yang menuntut warganya menjadi anggota dari agama tertentu. Bisa dimengerti kalau umat tidak tertarik untuk terlibat dalam kegiatan Gereja yang sering dianggap "membuang waktu."

Hal yang tidak relevan, tidak berguna, biasanya sulit dipertahankan. Hanya orang-orang yang takut saja yang bisa taat dan setia dalam satu organisasi yang tidak relevan untuk hidupnya. Peraturan yang kaku dan sangsi yang tegas diciptakan untuk melahirkan ketertundukan mutlak para anggota.

Mengapa para pastor cenderung bersikap otoriter? Karena hanya dengan gaya seperti itulah Gereja yang tidak relevan ini bisa dipertahankan. Dengan demikian, dapat dilihat lingkaran setan dalam tipologi gereja seperti ini. Kekuasaan mutlak para pastor menyebabkan Gereja tidak relevan, dan gereja yang tidak relevan menuntut gaya kepemimpinan yang otoriter untuk mempertahankannya. Pemusatan kekuasaan Gereja pada para imam/pastor dengan kekuasaan mutlak ini semakin mengekalkan model Gereja kultis yang pada gilirannya membuat gereja semakin tidak relevan untuk kebanyakan umatnya. Lingkaran setan ini hanya mungkin dipecahkan kalau kita kembali ke semangat awal Yesus yakni Gereja sebagai komunitas yang membebaskan.

\section{Imam-Awam bekerja sama membangun tata dunia}

Gereja yang terlalu berpusat pada pastor/ imam tidaklah sesuai dengan semangat dari Konsili Vatikan II. Semakin disadari sekarang akan peran penting kaum awam dalam Gereja. Untunglah pada akhir-akhir ini model Gereja kultis ini semakin ditinggalkan. Sebagai buahnya adalah semakin berjalannya kerja sama antara imam dan awam (Prasetya, 2003:40).

Kerja sama antarara Imam-Awam mulai terjadi di keuskupan Sibolga, ketika model Gereja Kultis/ ritual "diubah" menjadi model Gereja perjuangan, Gereja pembebasan, dengan demikian Gereja lebih tanggap terhadap situasi kemasyarakatan; Gereja yang berkehendak mengembangkan Gereja yang berdaya, tidak bergantung pada pihak lain dan terlibat dalam perjuangan masyarakat manusia menuju kesejahteraan.

\section{Pemberdayaan petugas pastoral}

Salah satu langkah konkret yang telah diwujudkan dalam bekerja sama antara imam dan kaum awam adalah menemukan masalah-masalah di semua bidang kehidupan sosial. Dalam bahan bacaan utama tentang metode perubahan dikatakan demikian: "Gereja Kristus yang sungguh hadir di dunia adalah Gereja keuskupan yang bertekat untuk menanggapi masalahmasalah yang ada di masyarakatnya" (bdk. Keuskupan Sibolga, 2010)

Selain itu kerja sama antara imam dan awam dilanjutkan dengan pemberdayaan petugas pastoral. Pemberdayaan petugas pastoral dimaksudkan untuk: 
1. Meningkatkan kesadaran kritis para petugas pastoral: termasuk di sini Wawasan petugas pastoral tentang Gereja dan misinya, serta Wawasannya tentang konteks pastoral.

2. Mengembangkan komitmen untuk menjalankan tugas secara benar dan solidaritas dengan umat yang didampingi.

3. Meningkatkan ketrampilan dalam pelbagai bidang: kemampuan untuk mendampingi perjuangan kemasyarakatan di komunitasnya dalam jejaringan dengan komunitas lain, orang perorangan dan organisasi lain.

4. Mengembangkan pengalaman akan Allah dalam situasi riil perjuangan masyarakat.

Para petugas pastoral yang sudah diberdayakan ini diharapkan akan memberdayakan komunitas-komunitas basis yang terdiri dari:

1. Komunitas territorial: stasi/lingkungan atau kelompok yang lebih kecil kalau stasi/lingkungan terlalu luas.

2. Komunitas kategorial: pengelompokan menurut profesi, umur, dll.

Komunitas basis dan jejaringan basis dimaknai sebagai wadah di mana kegiatan transformasi Gereja dijalankan menuju cita-cita yang ditetapkan dalam visi Keuskupan Sibolga. Komunitas basis boleh dikatakan sebagai kereta pendorong perobahan. Kalau petugas pastoral boleh dibayangkan sebagai pendayung becak, maka komunitas basis merupakan becak yang didayung oleh pendayung becak.

Dalam rangka pengembang basis ini, petugas pastoral dituntut untuk memiliki (bisa dibuat dalam kotak informasi untuk ditayangkan):

1. Wawasan yang jelas tentang misi Gereja

2. Wawasan yang jelas tentang Situasi pastoral

3. Ketrampilan untuk memfasilitasi umat, antara lain dalam hal:

a) Pengembangan iman yang berakar dalam situasi setempat

b) Pengembangan kesadaran kritis

c) Kemampuan dan kenekatan berjuang

d) Kemampuan untuk mengembangkan masyarakat dalam pelbagai bidang

e) Kemampuan berorganisasi dan jaringan

f) Pengembangan kemampuan pendanaan

4. Kemampuan bekerja dalam organisasi dan jaringan.

Proses pemberdayaan di basis-basis ini diharapkan bisa menghasilkan komunitaskomunitas yang memliki:

1. Kesadaran kritis 
2. Kemandirian dalam solidaritas

3. Ketrampilan-ketrampilan yang niscaya untuk menanggapi situasi

4. Jejaringan perjuangan

5. Pengalaman akan Allah sebagai Pembebas dalam konteks perjuangan kemasyarakatan yang bisa memberikan ilham, semangat dan daya dorong yang memungkinkan perjuangan kemasyarakatan bisa bertahan.

Diagram berikut ini coba memperlihatkan strategi yang direkomendasikan dalam buku perencanaan strategis pastoral Keuskupan Sibolga 2010-2014.

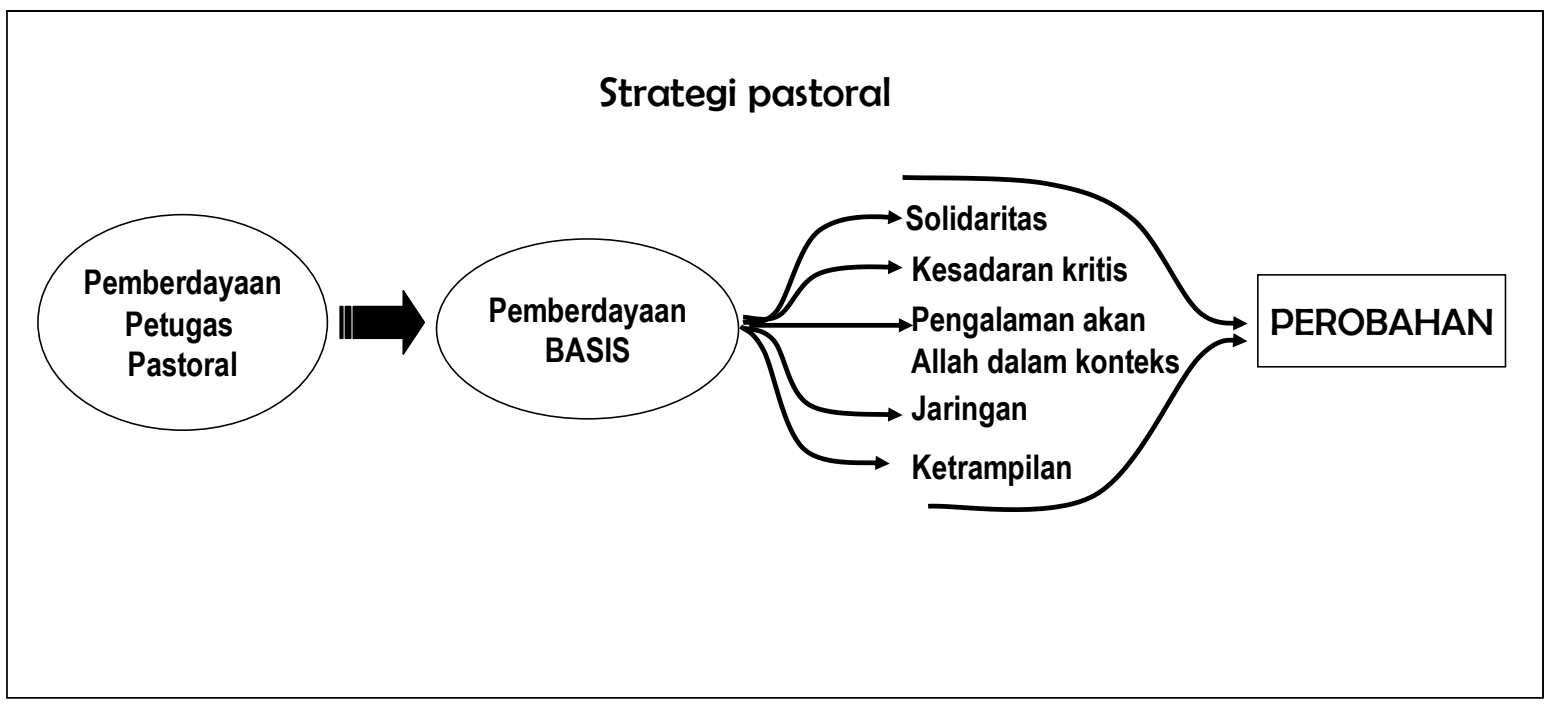

Dalam buku perencanaan strategis Pastoral Keuskupan Sibolga, 2010-2014, pengembangan basis antara lain meliputi beberapa kegiatan berikut ini:

a) Pengembangan rayon contoh di 5 paroki dimana program pastoral akan dijalankan secara intensif.

b) Pengembangan beberapa stasi contoh di beberapa paroki untuk beberapa program transformasi sosial.

c) Pengembangan semua program di masing-masing komunitas, khususnya komunitas contoh bertolak dari isu utama di komunitas itu sebagai pintu masuk.

\section{Praksis pastoral}

Maka dalam pelaksanaan pastoral di keuskupan Sibolga dipegang beberapa hal berikut ini: 
1. Pastoral harus bersifat kontekstual

a) Pastoral hanya menjadi praktek pembebasan ketika menjawabi konteks manusia jaman ini dalam pelbagai bidang (ekonomi, politik, sosial, budaya, agama-gama dan ideologi). Pastoral adalah jawaban terhadap masalah manusia.

b) Gereja hanya bisa menjadi wadah pembebasan dan pastoral menuju masyarakat baru kalau ia hidup ditengah dunia dengan segala kebobrokannya dan ikut berjuangan bersama dengan semua orang dan kelompok yang berkendak baik (dimensi solidaritas dalam perjuangan).

c) "Gereja mempunyai tugas yang sama seperti sebelumnya, yakni menyembuhkan orang-orang dari dosa-dosa dan menghantar mereka ke kehidupan kekal, tetapi itu harus dimulai dari situasi di dalam dunia di mana Gereja bertugas untuk menanamkan Kerajaan Allah, sekarang juga" (Romero, 2006:16); (Prasetya, 2007:28).

2. Pastoral harus bersifat partisipatip

a) Pembebasan hanya terjadi ketika orang tertindas menyadari ketertindasannya dan ikut ambil bagian dalam perjuangan menentang struktur penindasan: proses penyadaran dan solidaritas lintas kelas.

b) Pastoral hanya menjadi praktek pembebasan kalau menjadi karya umat. Umat sungguh dilibatkan, bukan hanya pada tahap melaksanakan program, tetapi pada seluruh proses pastoral.

c) Komunitas basis harus difasilitasi untuk membicarakan masalah-masalah yang dihadapi, secara kritis menganalisis sebab-sebab munculnya masalah, menentukan secara bersama-sama jawaban terhadap soal dan bergerak bersama-sama dalam praksis pastoral

3. Tindakan pastoral harus memiliki opsi yang jelas

a) Tindakan pastoral adalah keberpihakan, bukan sesuatu yang netral. Keberpihakan di sini ditujukan kepada mereka yang lemah, tertindas dan tersingkir dalam masyarakat. Keberpihakan ini terjadi bukan karena mereka benar, melainkan karena mereka menderita.

b) Perencanaan dan aktivitas pastoral hanya berhasil kalau orang-orang tersingkir ini diperhatikan dan diberdayakan.

c) Kegembiraan dan harapan, duka dan kecemasan orang-orang zaman sekarang, terutama kaum miskin dan siapa saja yang menderita, merupakan kegembiraan dan harapan, duka dan kecemasan para Murid kristus juga (GS. 1)

4. Pastoral harus diilhami oleh Sabda Allah. 
a) Apa yang direncanakan dan dikerjakan dalam karya pastoral haruslah kehendak Allah, bukan kehendak orang perorangan. Karena itu proses penemuan kehendak Allah dalam situasi hidup, dalam komunitas dan refleksi biblis harus difasilitasi dalam proses pastoral.

b) Inspirasi Sabda Allah ini menjadikan karya pastoral kita khas Kristen.

\section{Penutup}

Dikotomi imam-awam tidaklah sesuai dengan paham Gereja menurut Konsili Vatikan II yang melihat bahwa imam dan awam mempunyai peran yang sama-sama penting di dalam Gereja membangun dunia. Mereka dengan caranya masing-masing yang khas berperanan dalam membangun dunia. Dan sebagaimana sudah dikatakan bahwa fungsi dalam mengemban imamat Yesus Kristus dan corak hidup antara Imam dan Awam adalah berbeda, namun keduanya merupakan anggota-anggota Umat Allah (LG. 9). Lumen Gentium 32 menegaskan bahwa kaum Awam memiliki martabat yang sama dengan para diakon, imam dan uskup. Bahkan LG. 32 mengatakan bahwa sebagai Umat Allah kaum awam bersaudara dengan para diakon, imam dan uskup.

Maka, semestinya antara imam dan awam tidak bertentangan atau bersaing, namun bekerja sama. Kerja sama imam dan awam di dalam Gereja Katolik menunjukkan kekayaan rahmat Tuhan yang begitu kaya di tengah-tengah Umat Ciptaan-Nya. Seperti yang dikatakan oleh Santo Paulus "Satu tubuh tetapi banyak anggota". Selain itu kerja sama imam dan awam di dalam Gereja Katolik menunjukkan bahwa perjalanan kehidupan dan perkembangan Gereja Katolik tidak dapat dilepaskan dari berbagai aspek, baik itu aspek ilahi maupun lahiriah. Kedua Aspek ini diharapkan dapat berjalan seiring sejalan. Keduanya diharapkan dapat saling melengkapi dan menyempurnakan, sehingga Gereja Katolik dapat hidup dan berkembang secara utuh dan menyeluruh. Tentu hal ini tidak mudah tetapi justru inilah yang diharapkan menjadi salah satu perjuangan umat beriman Katolik, yaitu Gereja Katolik tidak jatuh dalam situasi hanya mementingkan salah satu aspek dan melupakan aspek lainnya.

\section{Kepustakaan:}

Konferensi Waligereja Indonesia. Dokumen Konsili Vatikan II. Jakarta: Obor, 1993.

Konferensi Wali Gereja Indonesia. Iman Katolik. Yogyakarta-Jakarta: Kanisius-Obor, 1996.

Keuskupan Sibolga. Gereja Mandiri Solider dan Membebaskan: Rencana Strategis Pastoral Keuskupan Sibolga 2010-2014, 2010.

Gitowiratmo. Seputar Dewan Paroki. Yogyakarta: Kanisius, 2003.

Prasetya, L. Keterlibatan Imam Awam sebagai anggota Gereja. Malang: Dioma, 2003. 
--------. Karya Penggembalaan Dewan Paroki. Yogyakarta: Kanisius, 2007.

Sinode Para Uskup. Christi Fideles Laici. Jakarta: KWI, 1987

Yohanes Paulus II. Pastores Dabo Vobis. Jakarta: KWI, 1992.

$* * *$ 